\title{
The Third Age: Reflections on Our Hidden Material Core
}

\section{Lenart Škof ${ }^{1}$}

Published online: 4 June 2020

(C) The Author(s) 2020

\begin{abstract}
This paper deals with the concept of three eras, as brought to us firstly in the Babylonian Talmud, and later reshaped and reformulated by Christian theologians Joachim of Fiore, Amalric of Bène, and finally by Luce Irigaray. In the first part, we start with the idea of the three eras. This is followed by a critical approach to Sloterdijk's You must change your life in which religion is substituted by the anthropotechnics. We argue that even in these secular times, the salvation history still remains unfulfilled and that our world is in need of a new, post-Christian materially spiritual narrative. The second part is entirely dedicated to Amalricians and their teachings. Also by tackling strong Islamic influences, we try to find a new opening towards the post-Christian era beyond the mentioned anthropotechnics/atheism divide. In the third part, the Age of the Spirit is approached and defined as a future messianicutopian era in which a hidden and forgotten inner spiritual core will be revealed to us and in which humanity will give itself a gift of becoming spiritually transformed and divinized.
\end{abstract}

Keywords Joachim of Fiore - Amalric of Bène - Antinomianism - The age of the spirit . The third age · Luce Irigaray · Messianism · Post-Christianity · Peter Sloterdijk $\cdot$ New materialism

\section{The Three Eras}

At the beginning of this essay, let us look at the words on three eras from the Jewish tradition, originating from around $600 \mathrm{AD}$. In the 'Abuda Zara' tract of the Babylonian Talmud, we read:

Lenart Škof

lenart.skof@guest.arnes.si; https://zrs-kp.academia.edu/LenartŠkof

1 Science and Research Centre Koper, Institute for Philosophical Studies, Garibaldijeva 1, 6000 Koper, Slovenia 
The disciples of Elijah taught: The world will continue for six thousand years, the first two thousand of which were a chaos (Tahu), the second two thousand were of Torah, and the third two thousand are the days of the Messiah, and because of our sins many years of these have elapsed, and still he has not come. ${ }^{1}$

The three ages, as propounded by the authors of the Babylonian Talmud, refer to the chaotic age before the Law, to the age of the Law of Torah, and to the future Messianic age which is still to come. In the Middle Ages, this thought clearly resounded in the teachings of Joachim of Fiore (1135?-1202) whose idea was that history was divided into three ages - the Age of the Father (Old Testament), the Age of the Son (New Testament and Church), and the Age of the Spirit (Third Testament and new Spiritual Church) which is still to come and in which new religious orders would inaugurate a new Spiritual Church here on the earth. ${ }^{2}$ The same teaching was then also one of the sources for the heretic medieval sect of Amalricians, and, in the most recent form, it reappeared in Hegel and Schelling, and was finally revived in an idiosyncratic way in Luce Irigaray's teaching of about 'the Age of the Spirit' (also equally called the Age of the Breath), in which the task of humanity - now based on a respect of sexual and religious difference(s) - will itself become the divine spirit, or divine breath. For Irigaray, there is one distinctive feature of this new or future era, namely, that in this era it will be possible to reunite 'the breath of the woman-mother with the divine redemption of humanity'. ${ }^{3}$ The third age, for Irigaray, will thus suspend the more patriarchal or masculine theological settings or spiritual environments of the first and the second age. In this particular model of history, she has no close contemporaries within contemporary philosophy. ${ }^{4}$

But let us first posit a preliminary question on an alleged controversy of the fields of ethics and theology. In his seminal book You must change your life, Peter Sloterdijk starts with the reformulation of one of the most famous sentences in philosophy - now in the form of 'A spectre is haunting the Western world - the spectre of religion. ${ }^{5}$ In the times of the huge migration flows from the beyond which in the recent decades for Sloterdijk already looked like 'an aspect of a mass exodus', ${ }^{6}$ there exists for him neither 'religion' nor 'religions' in the times of this grand exodus. What remains instead are various practices and operations that provide or improve our qualifications for the ever next practice - in terms of our philosopher-instead of an obsolete but once allpowerful world, still having a character of a theotechnics, we are left with the reign of the anthropotechnics. This would now mean that after exhausted and weary Homo

\footnotetext{
${ }^{1}$ The Babylonian Talmud, tr. by Michael L. Rodkinson, Book 9 (Tract Abuda Zara), Vol. 1 (Boston: Boston New Talmud Publishing Company, 1918), Ch. 1, p. 16.

${ }^{2}$ For these ideas, Joachim of Fiore was of course regarded in his time to be 'a prophet of the Antichrist'. See G. Dickson, 'Joachism and the Amalricians', Florensia 1, 1987, p. 35. This movement and related movements that were coming in the twelfth century (Amalricians, among others) have indeed been called with the name 'Antichurch' by Ernest Bloch. See E. Bloch, Avicenna and the Aristotelian Left (New York: Columbia University Press, 2019), 29 ff.

${ }^{3}$ Luce Irigaray, Key Writings (London/New York: Continuum, 2004), pp. 165-170 (Ch. 'The Age of the Breath'). For the citation, see p. 168.

${ }^{4}$ We need to add that in her writings Irigaray does not mention either Joachim of Fiore or Amalric of Bène. The same applies to Hegel as he gives no source nor cites Joachim of Fiore in his writings.

${ }^{5}$ P. Sloterdijk, You Must Change Your Life: On Anthropocentrics, tr. by W. Hoban (Cambridge: Polity, 2013), p. 1.

${ }^{6}$ Ibid., p. 2.
} 
faber, also Homo religious should take a well-deserved farewell. Our future will now be running "under the sign of the exercise" and the question now is whether this necessary turn from vertical metaphors and acrobatics in religion into their nineteenth (Feuerbach, Nietzsche) and twentieth century horizontal usages is what has now finally been superseded by the era of exercises. According to Sloterdijk, we could perhaps talk about three eras, as it were (i.e. per analogiam) - the vertical age (typical in the parable of Jacob's ladder, or in Dionysius the Areopagite's mystical theology, for example), the horizontal age (which still is characterized by a few last vertically designed, but already metaphysically weakened denominators such as, Nietzsche's Übermensch), and, finally, the real horizontal age of exercises-the common and future age of anthropotechnics. In this view, You must change your life becomes a new absolute imperative, now operating under the qualifier of ethical difference, but without any religious connotations whatsoever. The substitution of all forms of religion and theology with ethics and its new absolute imperative is therefore accomplished. But more than that should be desired and an access to the interiority and future form(s) of religion should remain open and vital in this era as well.

Let us now approach Joachim of Fiore: what Gianni Vattimo finds interesting about his thought in After Christianity is that salvation history is still in progress, here and now, and perhaps this sounds rather paradoxically and counterintuitive than logical - namely that in our global, decentralized, and too often cynical world that is at the same moment extremely socially or ethically vulnerable and environmentally fragile - we could talk of any kind of salvation at all. Vattimo argues: 'we can speak of prophecies of the future only because salvation history remains unfulfilled.' ${ }^{,}$What then if Sloterdijk's parable of huge migration flows from the beyond should have been accompanied with another, yet more inward movement still to be revealed to us? What if instead of triumphantly exposing and counting cadavers or dead bodies of various gods and demigods, and their religious and secular ideologies that we first invented, then worshipped and finally renounced and deserted (too often in terror and death), we try to consider another narrative - one less grandiose and of a much more delicate kind? One of a search for pulsation of religion in ourselves, for the return of charity/love into our tired and seemingly empty salvation history narratives - one that is perhaps not yet visible or tangible among us and our ethically fractured communities but is as concrete and strong as our highest hope? If we believe Joachim of Fiore, there is only one name that deserves and needs to be elevated to the heights, and cherished in the future - and this is charity:

There are three ages of the world indicated by the sacred texts. The first is the stage in which we have lived under the law; the second is that in which we live under grace; the third is one in which we shall live in a more perfect state of grace. . . . The first passed in slavery; the second is characterized by filial slavery; the third will unfold in the name of freedom. The first is marked by awe, the second by faith, the third by charity. . . . The first period regards the slaves; the second regards the sons; the third regards the friends. . . . The first stage is ascribed to the Father, who is the author of all things; the second to the Son, who

\footnotetext{
${ }^{7}$ Ibid., p. 4.

${ }^{8}$ Cit. from G. Vattimo, After Christianity, tr. by Luca D’Isanto (New York: Columbia University Press, 2002), p. 29.
} 
has been esteemed worthy to share our mud; the third to the Holy Spirit, of which the apostle says, "Where the spirit of the Lord is, there is freedom". 9

According to Joachim of Fiore, the three stages are accomplished in the third, e.g. final historical era, also known in his teachings and prophecies as the Sabbath Age, in which this earthly world will be transformed into a kingdom, or a terrestrial era 'without war, without scandal, without worry or terror'. ${ }^{10}$ According to our thinker, the first status originated with Adam and was completed with Christ; the second status began with Uzziah (King of Judah) and was near its end in the time of Joachim of Fiore; the third status had already begun with Saint Benedict of Nursia and will end with the conclusion of history. ${ }^{11}$

In her seminal essay on the originality and influence of Joachim of Fiore, Marjorie Reeves argues that similar ideas flourished in Europe well before the thirteenth century. So long as Christians stood outside the secular order, the ideas of a coming age could not be understood in a historical manner - as in Joachim of Fiore. When in Eusebius's History of the Church the Roman Empire became understood as 'the latest instrument of God' in the long Judeo-Christian history from Abraham to Constantine, it was possible to introduce, as it were, a proto-Hegelian understanding of the historical stages into the theology. ${ }^{12}$ But Montanus (second century) was the first to contend that he was living in the Age of the Holy Spirit, which is to succeed the Ages of the Father and of the Son. ${ }^{13}$ But it was St. Augustine who derived from St. Paul the triadic pattern of six great ages (aetates) - in whose three consecutive times/tempora - of ante legem, sub lege, and finally sub gratia flourished. These six ages, symbolizing the six days of Creation, were sealed or concluded with the Seventh or Sabbath Age (cf. also seven seals from the Apocalypse). And Honorius of Autun (c. 1080-1154?) first elaborated on the three stages as found within the six great ages as tempus ante legem from Adam to Moses, tempus legis from Moses to Christ, and, finally, tempus gratiae reaching

\footnotetext{
${ }^{9}$ Ibid., $29 \mathrm{f}$. The citation is taken from Vattimo. Main thoughts on the three eras appear in Joachim's book Liber figurarum, in: Il libro delle Figure dell'Abate Gioacchino da Fiore, ed. by Leone Tondelli, Marjorie Reeves, and Beatrice Hirsch-Reich, 2 vols. (Turin: Società editrice internazionale, 1953). On Liber figurarum see an excellent study by M. Riedl, 'A Collective Messiah: Joachim of Fiore's Constitution of Future Society', Mirabilia 14 (Jan-Jun 2012), pp. 57-80. As explained about Liber figurarums by Riedl: 'The so-called Liber Figurarum contains a collection of symbolic drawings attributed to early followers of Joachim of Fiore. The Liber was composed only in the 20th century by Leone Tondelli, largely based on 13th-century codices from Dresden, Oxford, and Reggio Emilia; yet of most drawings one can safely say that they have been created from original drafts by the Calabrian abbot himself.' (58) And about the three eras, Riedl adds: 'The revelation of the Father brought about the patriarchal order of Israel, as described in the Old Testament; the revelation of the Son led to the creation of the clerical church; and, finally, the soon-to-be-expected third dispensation of the Holy Spirit would bring about the monastic ecclesia spiritualis.' (Ibid.) About the details of a future monastic society, see Riedl's extensive description in his paper.

${ }^{10}$ Cit. after B. E. Whalen, Dominion of God: Christendom and Apocalypse in the Middle Ages (Cambridge, MA: Harvard University Press, 2009), p. 100. The passage is from Joachim of Fiore's Liber de concordia novi et veteris testamenti.

${ }^{11}$ The Dialogues of Pope Gregory the Great also gives credit to Benedict's twin sister Scholastica whose spiritual call is as potent and parallel to her brother's and written up with some reverence in The Dialogues. I thank Shé M. Hawke for reminding me of this important mention on the unjust oblivion of sister Scholastica from the history of Christianity.

${ }^{12}$ M. Reeves, 'The Originality and Influence of Joachim of Fiore', Traditio, Vol. 36 (1980), p. 271.

${ }^{13}$ Cf. ibid., $272 \mathrm{n} 15$.
} 
from the Incarnation to the Second Coming. ${ }^{14}$ But Honorius would still remain Augustinian in a way that according to him the Seventh or Sabbath Age would still rest beyond/outside the Last Judgement. Joachim who read Honorius's writings would now change and historize this constellation. Finally, Rupert of Deutz was the first to clearly relate three stages to the three Persons of the Trinity, linking this Trinitarian dynamics also with the progressive movement through history. And, lastly, Eberwin of Steinfeld (d. April 10, 1152) and Hildegard of Bingen (1098-1179) would now be able to directly link the three ages with the process of perfection within the earthly Church in which new humble perfecti would emerge and surpass or outgrow the old spiritual patterns: for both blessedness is to take place on earth. ${ }^{15}$

Although the teachings of Joachim of Fiore about the division of time were based on the idea of the Trinity, his theology was still largely focused on the 'political' idea of a millennial transformation of society towards the final eschatological unification of Christians, Jews, and Greeks in one Roman Church. Thus, the status of the Father was related to the non-believing Jews and their subsequent conversion, as the status of the Son was related to the Gentiles or heretical Greeks and their conversion. In the third, final age, humanity would witness the final unification of all under the Holy Spirit with the spiritual guidance of spiritual men (Christian monks respectively), who would guide this world in an earthly Sabbath age. Related to the era of crusades of which Joachim of Fiore bore witness and was both their supporter and a critic, his teachings of course are one of the earliest contributions to the political theology as such. ${ }^{16}$ Still, according to Vattimo and his interpretation of the abbot from Calabria this still remains a prophecy with an important 'discovery that historicity is constitutive of revelation. ${ }^{, 17}$ But behind and as also beyond a more narrow interpretation or reading of his innovative thoughts, there is a strong ethico-eschatological message that we want further to explore in this essay: namely, that the third age-if we may risk this idea here - actually is a pulsation of divine life (or religion) in our most inward spiritualmaterial layers still to be revealed and opened to us. If this could be true, then the Age of the Spirit actually is the future or coming Messianic Age of the renewed religious and aesth/ethic sensibilities, a feature of divinization, based on the hidden or forgotten materiality of breath:

We should not forget that the world spirit (pneuma) means etymologically breath, wind, blowing, something volatile, fleeting, of which thought lost the memory when it began conceiving of spirit as the evident and indubitable foundation of self-consciousness, up to Hegel's "absolute spirit". ${ }^{18}$

Clearly, this fully resounds with Luce Irigaray's version of the three ages teaching as leading to the future Age of the Breath in which the task of humanity will be to become itself divine breath. But it is in one of the immediate successors of Joachim of Fiore-

\footnotetext{
${ }^{14}$ Cf. ibid., 277f. Interestingly enough, Marjorie Reeves does not mention Amalric and his school in her otherwise excellent study.

${ }^{15}$ Cf. ibid., $285 \mathrm{f}$.

${ }^{16} \mathrm{Cf}$. Whalen, Dominion of God, p. 116.

${ }^{17}$ Vattimo, After Christianity, p. 31.

${ }^{18}$ Ibid., p. 52. On the history of this oblivion of the breath in the history of philosophy, see Atmospheres of Breathing, ed. by. L. Škof and P. Berndtson (New York: SUNY Press, 2018).
} 
namely, in Amalric of Bène's panentheistic and naturalistic thought, that these ideas already found its first earthly incarnation.

\section{Amalric of Bène on the Way to Post-Christianity}

According to Agamben, the meaning of ethics is revealed to us only when we understand that 'good is revealed to consist in nothing other than a grasping of evil', and when evil is recognized by us as the forgetting of the 'transcendence inherent in the very taking place of things. ${ }^{19}$ God or good, according to Agamben, is the taking-place of the entities - such as that being-worm of the worm, or the being-stone of the stone is now regarded to be divine. Good, therefore, means that 'God is all in all' and this appropriation or understanding of the Platonic doctrine of chora, according to Agamben, was also the doctrinal content of the Amalricians, who, similarly to Albigensians and Cathari and their perfecti, were regarded perfect or impeccable by themselves and thus believed that it is in them and in their inherent divinity that the new spiritual age has just been revealed to humanity. The transcendence, therefore, does not dwell as a supreme entity somewhere above all entities and things, but, rather inversely, 'the pure transcendent is the taking-place of every thing. 20

But who were the Amalricians? How was it possible for the early thirteenth century small but already influential Paris group of theologians to become so radically postChristian in the midst of Latin Christianity? Master Amalric or Amalric of Bène (11501206/1207) was the founder of a medieval heretical sect that was known under the name of their founder - the Amalricians. Next to Master Amalric was a philosopher David of Dinant (ca. 1160-ca. 1217) who was among the most prolific members of the sect. David of Dinant, who outlived his close friends, was known for his pantheisticmaterialistic Deus, hyle et mens una sola substantia sunt sentence, which was preserved by Albertus Magnus. ${ }^{21}$ It was on 20 November 1210 that ten of the most important followers of Master Amalric were burnt at the stake in front of a large crowd of spectators in Paris. Other followers of the sect were imprisoned or forced to abandon their heretical teachings. Amalric himself died in 1206/1207 after being condemned shortly before. In 1210, Amalric was excommunicated posthumously and his bones were exhumed from their resting place and transferred to an unconsecrated ground for his second burial and by 1215 the sect was virtually annihilated. Importantly, among the Amalricians, there were many women and the sect gathered among its members people from the lower classes - such as various handworkers and peasants. With their orientation towards plebeian social classes, Amalricians therefore also had a clear political dimension and a social programme for an earthly kingdom of men and women of their time beyond Church and state hierarchies and class divisions. Any human

\footnotetext{
${ }^{19}$ Agamben, The Coming Community (Minneapolis/London: University of Minnesota Press, 2009), cit. on pp. 12 and 14.

${ }^{20}$ Ibid., p. 14.

${ }^{21}$ Bloch, Avicenna and the Aristotelian Left, p. 30.
} 
being, according to the Amalricians, could become divine in itself in her or his lifetime. $^{22}$

At the time of Master Amalric's teaching, the University of Paris was already famous for theological learning and was under the protection of King Phillip Augustus; the university was the very centre of theological studies of the Western Christian world. But at the same time the Church and political leaders were already firmly determined to get rid of heresies in the land - and the Crusades against Albigensians and Cathari had just begun in 1209 and 1210. At the university, Aristotle's books (on natural philosophy) and Scotus Eriugena's books (De Divisione Naturae) were already banned as dangerous. Furthermore, the sect of Amalricians, which already outgrew the narrow academic environment and became by then the evangelical movement with many important intellectuals as their followers (and already was present as a new teaching among the plebeian social classes), was recognized as extremely dangerous for the Church; thus, it was quickly decided by Church leaders for the sect to be stopped and annihilated. $^{23}$

Now, apart from his relation to Scotus Eriugena's early teachings (which from their original idealistic form were now materialistically reshaped by Master Amalric), as a propounder of the teaching of the three stages, Master Amalric must have been in touch with the Joachite prophecy. Either in Rome or at the University of Paris, Amalric must have encountered these thoughts in order to reformulate and further develop them with his friends and followers into the doctrine of the three ages of history. ${ }^{24}$ With these teachings, Amalricians fully rejected the Church hierarchy and instead prophesized about the worth and dignity of ordinary men and women of their time and therefore already incorporated sexual difference into their transformed religion. ${ }^{25}$ But before we elaborate on their teachings, it is necessary to mention important Islamic influences as they were present in the left-wing Aristotelianism, ${ }^{26}$ especially in Ibn Sina/Avicenna (980-1037) and Ibn Rushd/Averroës (1126-1198), which already contained materialistic and pantheistic/panpsychistic traits and could also quickly become widespread among the Christian schools of their time. In Avicenna's vitalist materialism form does not precede matter anymore: matter is both primordial and co-eternal — with the form. Matter/nature is now a subject for the first time - and 'contains within it a possibility of its own emergence. ${ }^{27}$ According to Averroës's Destructio Destructionis, it is in Philosophia Orientalis, which is lost and only known from indirect sources, that Avicenna supports the claim that '[t]here must exist a spiritual force which is diffused in all the parts of the universe in the same way as there is a force in all the parts of a single animal which binds them together.' This beautiful intuition of Avicenna rests on

\footnotetext{
${ }^{22}$ Hermann Ley, Studie zur Geschichte des Materialismus im Mittelalter (Berlin: VEB Deutscher Verlag der Wissenschaften, 1957), $214 \mathrm{ff}$. Also, other religious sects of that time shared a similar social message-such as Valdesians, Cathars, or Albigensians.

${ }^{23}$ On these and related events in the beginning of the thirteenth century see G. Dickson, 'The Burning of the Amalricians', Journal of Ecclesiastical History, Vol. 40, No. 3, July 1989, pp. 347-369.

${ }^{24}$ Cf. Dickson, 'Joachism and the Amalricians', 38.

${ }^{25}$ I think of Irigaray's thesis, that is if a woman is 'divine from birth', and thus more closely related to the spiritual breath, then it is logical that the neglect of the feminine aspects in almost all institutionalized religions is related to the need of the man for religious education which he actually needs for himself to attain his redemption (see Key Writings, p. 165).

26 This label comes from Ernest Bloch; see his excellent Avicenna and the Aristotelian Left.

${ }^{27}$ Ibid., p. 21. This thought comes from Avicenna's Metaphysika.
} 
his presumption that knowledge (and within it, science) actually takes precedence over the faith. Averroës's own philosophy was similarly rooted in his own take of the Aristotelian teachings on the ontological primacy of the uncreated and eternal matter, which also represented the traits of the emerging more progressive social classes and their interest in natural sciences of the Islamic twelfth century. ${ }^{28}$ According to Herman Ley, it is precisely in this overturning or overcoming of Aristotle's classical dýnamisenérgeia scheme that later actually helped the West make the transition towards natural sciences in the Renaissance.

Now, to return to Amalric of Bène's teachings, there is perhaps no better example than to read the following excerpt by Roberto M. Unger, another great thinker on a path of post-Christianity:

The antinomian element in Christianity, so close to the wellsprings of the faith, remains, however, a strength rather than a weakness. Antinomianism is intimately related to the conception of the person as situated and embodied spirit, transcendent over the institutional and conceptional frameworks that shape him and incapable of being wholly defined by circumstance. ${ }^{29}$

This precisely was the case of Master Amalric and Amalricians. The sources for getting closer to what Amalricians believed are scarce and largely depend on an official document of the Church which was issued by a provincial synod at Paris in 1210 upon the conviction of the sect. ${ }^{30}$ Charges against Amalricians consisted of three themes: 'pantheism, the attainment of spiritual perfection here on earth, and the antinomian and antisacramental implications of the Amalricians' views on the preceding two topics. ${ }^{31}$ Within their concept of the third age- the Age of the Spirit-Amalricians believed in an ontological continuity between God and creation so as to bring deification of men and women within reach already in their lifetime. Apart from this, Amalricians also believed that they have been granted a very special place in the plan of salvation and thus that they indeed possessed grace of already being in the third age. Quite in line with Agamben's remarks on the meaning of ethics, Amalric and his followers indeed took the notion of 'God is all in all' seriously and understood salvation as the 'coming of the place of itself' - of each and every entity, from God to human being, from animal to a mineral or stone. The Age of the Spirit means that taking place of each entity, or its transcendence, implies a radically materialistic salvation theology. This

\footnotetext{
${ }^{28}$ Ley, Studie zur Geschichte des Materialismus im Mittelalter, pp. 132-144. As for Avicenna, also for Averroës, all becoming, change, and perishing in the world is rooted in matter. It is in this ontology that we can search for one of the decisive influences for the 'materialistic' developments within unorthodox Christian philosophy.

${ }^{29}$ Unger, The Religion of the Future (Cambridge, MA: Harvard University Press, 2014), p. 277 (my emphasis).

${ }^{30}$ For more on the literature and for an elaborate account on the very context of the suppression of the heresy, see J. M. M. H. Thijssen, 'Master Amalric and the Amalricians: Inquisitional Procedure and the Suppression of Heresy at the University of Paris', Speculum 71 (1996), pp. 43-65. An important source also is a book by G. C. Capelle, Autour du Décret de 1210: Amaury de Bène. Etude sur son panthéisme formel (Paris, 1932).

${ }^{31}$ Thijssen, p. 46.
} 
'absolute pantheism' of Amalricians therefore was in line with G. Bruno's and Spinoza's later forms of pantheism - for both counted as 'materialistic' as opposed to other 'idealistic' forms - if we have just Hegel in mind. ${ }^{32}$ An argumentation which we can get from Contra Amaurianos - and these most probably were the words of Amalricians, charged of heresy-is simply the following: 'What always in God is, is God. In God is but everything, because everything, that is created, was life in him. Therefore, God is all. ${ }^{33}$ Amalricians therefore believed that God is everywhere, and that God actually $d w e l l s$ in all things, thus: 'Inhabiting a Godfilled universe in which the Holy Spirit held sway and within which man might aspire to become a truly spiritual being, ${ }^{34}$ — this was the meaning of their antinomian and antisacramental teachings. For Amalricians, then 'just as the ceremonies of the old law ceased with the advent of Christ, so, too, the sacraments of the Church ceased to be operative with the coming of the Holy Spirit. ${ }^{35}$ Women and men, having the Holy Spirit incarnated within themselves, are now free and thus not dependent on any external power or law anymore. The highest law of humanity (and a new religion!) now is to become spiritual beings, here and now, on the earth. There will come the times when no war, no terror, no sin will inhabit this world. This is a real possibility now, if we employ the utopian, yet concretely and materialistically underpinned language of Ernest Bloch. ${ }^{36}$ The keys of the third age, as it were, lie hidden in our hearts. It is on us to resolve this riddle of all riddles - the taking-place of the post-Christianity in/as ourselves. Not an easy task at all. But we may believe in an event of its coming.

\section{The Third Age-Age of the Spirit}

It is time to approach the topic of the Age of the Spirit-in both a theological and an ethical sense, and as a sign of a future reconciliation between morality and religion. We have seen in the first part of this essay that the decisive point for historicization of the three ages was the positioning of the Roman Empire into the salvation history of the Judeo-Christian world. Now, this vision reappears for the second time-if we use the well-known sentence from Karl Marx's The Eighteenth Brumaire of Louis Napoleon-that history repeats itself, the first as tragedy, then as farce-through following constellation around

\footnotetext{
${ }^{32}$ Karl Albert, 'Amalrich von Bena und der mittelalterliche Pantheismus', in A. Zimmermann, Hrsg., Die Auseinandersetzungen an der Pariser Universität im XIII. Jahrhundert, Berlin, 1976, pp. 193-212. Cit. on p. 195.

${ }^{33}$ Albert, 'Amalrich von Bena und der mittelalterliche Pantheismus', p. 209: 'Quicquid in deo est, deus est. Sed in deo sunt omnia, quia, quod factum est, in ipso vita erat. Ergo deus est omnia.' Finally, for Albert, Amalricians are labelled as being idealistic and not materialistic, but this statement is to be counterweighted with his own strong Marxist view.

${ }^{34}$ Dickson, 'The Burning of the Amalricians', 358f.

${ }^{35}$ Ibid., p. 359.

${ }^{36}$ Bloch was hoping for a future age, which would be marked by the beginning of a new, collaborative phase, ending the alienation of humanity from nature, and, 'by extension, of humanity from itself.' ('Introduction' to Avicenna and the Aristotelian Left, p. xvi) Understood in a more open sense, this indeed is a religion of the future, and it is for this reason that Adorno so much disliked Bloch and even said that 'The Spirit of Utopia seemed to be written by Nostradamus itself.' (Ibid., p. xiii).
} 
Hegel's writings, as explained by Purushottama Bilimoria in his essay on Western orientalism and related concepts of philosophy of history:

Spectacularly, the night before the Holy Roman Empire fell to Napolean's thumbing Wellington boots at Jena in September 1806, Hegel completed his Phenomenology of the Spirit. The massive tome ends, appropriately, with an ontotheological schema reminiscent of Joachim of Fiore's announcement of a New Age of the Spirit to complete the Ages of the Father and the Son. And like Goethe, Hegel concluded that the irreversible event signaled the end of the Middle Ages. ${ }^{37}$

Although there are no citations from, or other concrete signs, of Joachim of Fiore in any of Hegel's writings, we still can contend that the entire phenomenologico-historical mission of Hegel's 'triadic' thought is marked by Joachite influence. We know that Hegel's absolute spirit is marked with an absolutely indispensable occidentalist tendency. In Schelling's late work Philosophy of Revelation, the German philosopher elaborates on the third age by making a more direct and more appropriate reference to Joachim of Fiore. According to Schelling, it is necessary to think of three successive ages in order to complete the world history with an Era of the Spirit. By referring to Jn 7,39 ('for as yet there was no Spirit, because Jesus was not yet glorified'), Schelling therefore makes clear reference to Joachim of Fiore and other heretical sects, as he writes, which knew and prophesized about the future time in which Christianity would really become the "religion of humanity., 38

From Joachim of Fiore to Schelling (but not Hegel), the third age was therefore announcing a Third Testament and a new Christianity-one that would now be inscribed in our hearts, and one that would be synchronized with the pulsation of religion in ourselves and indeed in our carnal and spiritual bodies. Luce Irigaray now describes the third age as:

an age which would permit to reunite it with other traditions and to overcome the opposition between matriarchy and patriarchy (...) In the third age of the history of Judeo-Christianity, after the age of the world's redemption, thanks to Mary and to Jesus, the task of humanity will be to become itself divine breath. ${ }^{39}$

\footnotetext{
${ }^{37}$ Purushottama Bilimoria, 'Philosophical orientalism in comparative philosophy of religion: Hegel to Habermas (\& Žižek)', Cultura Oriental, Vol. 2 (Jul-Dec 2015), No. 2, p. 49. The original paragraph appears in Hegel's Vorlesungen über die Geschichte der Philosophie, Werke 12 (Stuttgart: Suhrkamp, 1986), p. 417. The author wishes to acknowledge the comments of anonymous reviewers for their valuable suggestions, and especially for the comments that helped to expand and enrich this paper towards analyses of the Hegelian inheritance in the three ages thinking.

${ }^{38}$ F. W. J. Schelling, Philosophie der Offenbarung (Part II, Fourth Book), p. 70. Cit. from: Schellings Werke: Nach der Originalausgabe in neuer Anordnung, ed. Manfred Schröter (Munich: C. H. Beck, 1927-1959 and 1962-1971): 'Die dritte Zeit, die während der ganzen Schöpfung die zukünftige ist, in die alles gelangen soll, sey die Zeit des Geistes [..., as followed by] eine dritte Oekonomie, eine dritte Zeit bevorstehe, die Zeit des Geistes, welche das ewige Evangelium bringen solle.' (II/4, pp. 71 and 72; see p. 328 for the third age as an age of the religion of humanity when Christianity finally becomes 'erst wahrhaft offentliche Religion - nicht als Staats-religion, nicht als Hochkirche, sondern als Religion des Menschengeschlechts, das in ihm zugleich die höchste Wissenschaft besitzt'). For Jn 7,39 see: The Holy Bible, NRSV (Nashville: Thomas Nelson Publishing, 1989).

${ }^{39}$ Irigaray, Key Writings, 167f.
} 
This entirely post-Christian and post-masculinist religious constellation is now obviously not the task of only one sex, one culture, or one religious tradition anymore, but is mutually shared between the world traditions beyond any artificial dichotomies or antagonisms based on intellectual pride or prestige. According to Vattimo, we can speak of prophecies of the future only because salvation history remains still unfulfilled, and we have seen in Sloterdijk that an alternative to salvation within religion would only be in the descent from any of the remaining vertical layers of our religious experience into an era of exercises - the era of anthropotechnics. But there is another path, one that is not so much attached to getting to our self-affection through exercises, but rather is linked to a new way of self-affection, emerging from the spiritualbreathful being. The task now would be to become in tune with the process of the new spiritual transformation of humanity so as to become enlightened enough to hear the voice of the other, to detect his/her signs and gestures that call for a dialogue with him or her, or with nature in one of its incarnations. This rediscovery of our forgotten and hidden spiritual-material layer is a task for us also to learn how to ethically respond to the call of another human being or even of a non-human animal and their breathing. This now perhaps already hints towards a future post-religious status in which subtle divine/cosmic elements and related energies are activated in us by an enhanced mode of self-affection - as taking-place (Agamben) of divinity in ourselves - what now invites us to think towards the possibility towards the messianic event, which will be the time, when 'everything will be as it is now, just a little different. ${ }^{40}$ This difference, as a reconciliation of ethics and religion, is as subtle as spiritual breath that we share one with another: it is present in a little child, who now sleeps in tranquillity, and breathes in the atmosphere of peace; it is revealed in this world, when a little girl plays in the garden joyfully and calmly; it is time, when men and women breathe the air of mutual respect and hospitable exchange of their spiritual energies (in body, language, and spiritual gestures, as new rituals); it is the communal breath of peace, a pulsating of community, as it were, in the rhythm of peace; and, finally, it is a time of a new covenant with nature and its divine beings and their subtle bodies, as impregnated by the holy sap of the cosmic breath. Divine is the love for the other as other, divine is the praise of nature as nature, for Irigaray. ${ }^{41}$ And this is what Richard Rorty, as one of the last great American intellectuals, so beautifully described in his essay on the future of religion:

My sense of the holy, insofar I have one, is bound with the hope that someday, any millennium now, my remote descendants will live in a global civilization in which love in pretty much the only law. (...) I have no idea how such a society could come about. It is, one might say, a mystery. This mystery, like that of the Incarnation, concerns the coming into existence of a love that is kind, patient, and endures all things. ${ }^{42}$

\footnotetext{
${ }^{40}$ Agamben, The Coming Community, p. 52.

${ }^{41}$ Irigaray, Key Writings, p. 170. And also: 'God is us, we are divine if we are woman and man in a perfect way.' (p. 169).

${ }^{42}$ R. Rorty and G. Vattimo, The Future of Religion, ed. by Santiago Zabala (New York: Columbia University Press 2005), p. 40.
} 
The spiritual community of Amalricians knew and prophesized about this future and this love-when the body of humanity, and the body of nature and its beings will become impregnated with the holy breath, and thus be divinized.

Funding information Javna Agencija za Raziskovalno Dejavnost RS (J7-1824 and J6-8265). Javna Agencija za Raziskovalno Dejavnost RS (P6-0279)

Open Access This article is licensed under a Creative Commons Attribution 4.0 International License, which permits use, sharing, adaptation, distribution and reproduction in any medium or format, as long as you give appropriate credit to the original author(s) and the source, provide a link to the Creative Commons licence, and indicate if changes were made. The images or other third party material in this article are included in the article's Creative Commons licence, unless indicated otherwise in a credit line to the material. If material is not included in the article's Creative Commons licence and your intended use is not permitted by statutory regulation or exceeds the permitted use, you will need to obtain permission directly from the copyright holder. To view a copy of this licence, visit http://creativecommons.org/licenses/by/4.0/.

\section{References}

Agamben, G. (2009). The coming community. Minneapolis/London: University of Minnesota Press.

Bilimoria, P. (2015). Philosophical orientalism in comparative philosophy of religion: Hegel to Habermas (\& Žîžek). Cultura Oriental, 2(2), 47-63.

Bloch, E. (2019). Avicenna and the Aristotelian left. New York: Columbia University Press.

Capelle, G. C. (1932). Autour du Décret de 1210: Amaury de Bène. Paris: Etude sur son panthéisme formel. Dickson, G. (1987). Joachism and the Amalricians. Florensia, 1, 35-47.

Dickson, G. (1989). The burning of the Amalricians. Journal of Ecclesiastical History, 40(3), 347-369.

Hegel, G. W. F. (1986). Vorlesungen über die Geschichte der Philosophie (Werke 12). Stuttgart: Suhrkamp. Irigaray, L. (2004). Key writings. Continuum: London/New York.

Joachim of Fiore (1953). In L. Tondelli, M. Reeves, \& B. Hirsch-Reich (Eds.), Liber figurarum. Il libro delle Figure dell'Abate Gioacchino da Fiore, 2 vols. Turin: Società editrice internazionale.

Ley, H. (1957). Studie zur Geschichte des Materialismus im Mittelalter. Berlin: VEB Deutscher Verlag der Wissenschaften.

Reeves, M. (1980). The originality and influence of Joachim of Fiore. Traditio, 36, 269-316.

Riedl, M. (2012). A collective messiah: Joachim of Fiore's constitution of future society. Mirabilia, 14, 57-80.

Rorty, R., \& Vattimo, G. (2005). In S. Zabala (Ed.), The future of religion. New York: Columbia University Press.

Schelling, F. W. J. (1927-59 and 1962-71). Philosophie der Offenbarung, Viertes Buch. In M. Schröter (Ed.), Schellings Werke: Nach der Originalausgabe in neuer Anordnung. Munich: C. H. Beck.

Škof, L., \& Berndtson, P. (Eds.). (2018). Atmospheres of breathing. New York: SUNY Press.

Sloterdijk, P. (2013). You must change your life: on anthropocentrics, tr. W. Hoban. Cambridge: Polity.

The Babylonian Talmud (1918). tr. by Michael L. Rodkinson. Boston: Boston New Talmud Publishing Company.

The Holy Bible (1989). New Revised Standard Version. Nashville: Thomas Nelson Publishing.

Thijssen, M. M. H. (1996). Master Amalric and the Amalricians: inquisitional procedure and the supression of heresy at the University of Paris. Speculum, 71, 43-65.

Unger, R. M. (2014). The religion of the future. Cambridge: Harvard University Press.

Vattimo, G. (2002). After Christianity, tr. Luca D'Isanto. New York: Columbia University Press.

Whalen, B. E. (2009). Dominion of god: Christendom and apocalypse in the Middle Ages. Cambridge, MA: Harvard University Press.

Zimmermann A. (ed.) (1976). Die Auseinandersetzungen an der Pariser Universität im XIII. Jahrhundert (pp. 193-212). Berlin.

Publisher's Note Springer Nature remains neutral with regard to jurisdictional claims in published maps and institutional affiliations. 